\title{
Studies on Host Range and Biology of Mango Mealy Bug (Drosicha mangiferae) in Jammu Region
}

\author{
Bandana Bhau, Uma Shankar" and D.P. Abrol \\ Division of Entomology, Sher-e- Kashmir University of Agricultural Sciences and Technology, \\ Faculty of Agriculture, Chatha Jammu - 180009, J\&K, India \\ *Corresponding author
}

\section{A B S T R A C T}

\section{Keywords}

Mango mealy bugs,

Drosicha

mangiferae, Host

ranges, Biology,

Diapause.

Article Info

Accepted:

04 July 2017

Available Online:

10 September 2017
An extensive field survey conducted on its host ranges revealed that mango mealy bug (Drosicha mangiferae) was invariably found on variety of cultivated fruit and vegetable crops as well as on wild host crops growing in and around the fruit and vegetable crop ecosystem. The studies revealed that more than more than 37 host plants from 24 families were infested with four species of mealy bug. Studies on biology and duration of various life/developmental stages revealed that total period of activity of female on an average was $125.5 \pm 10.17$ days and Male $110.5 \pm 10.01$ days. The eggs laid in the soil cracks and crevices remained in diapause from June to the next season in January.

\section{Introduction}

Mango (Mangifera indica Linnaeus) is an important tropical fruit, grown in more than 100 countries of the world (Sauco, 1997). It is most popular fruit amongst millions of people in the Oriental region, particularly in IndoPakistan Sub-continent. India is the largest mango producer in the world (10.0 million tonnes) with 15 per cent share in the world mango market. Mango is grown in vast range of agro climatic conditions and attacked by over 500 species of insect pests (Tandon and Lal, 1981; Tandon and Varghese, 1985) where 21 species are most important pests particularly in oriental region (Tandon, 1978). Mango is usually attacked by four to five key pests damaging the crop to a considerable extent causing severe losses which includes fruit flies, stone weevils, mango hoppers, mealy bugs, scale insects and tree shoot borers. However, only a few important species are of major concern in Jammu region.

Among the insect pest listed as above, Mango mealy bugs (Drosicha mangiferae, Drosicha stebbingi and Rastrococcus iceryoides) (Hemiptera: Pseudococidae), the polyphagous pests of mango in India are recorded as serious pests from Asia on several host crops (Tandon and Verghese, 1985). The newly hatched nymphs ascend the trees, settle on inflorescence and feed by sucking sap and 
thereby causing flower drop and affecting fruit set. Serious attack by this insect follows drying of the leaves, terminal shoots, premature fruit fall. Earlier, mealy bug were considered to be minor pest in several crops have gained the status of major pest especially in cotton, vegetables and fruit crops. During last few years, mealy bug has become a major problem in several crops (Tandon and Lal, 1978). The management is difficult particularly in view of its behaviour and polyphagous nature. Therefore, the present investigation has been planned with the following objectives to study host plants and life cycle of mango mealy bug, Drosicha mangiferae.

\section{Materials and Methods}

The studies on the host range and biology of Mango mealy bug (Drosicha mangifera were carried out at three locations at Miran Sahib, Udheywalla and Akhnoor in a radius of 10 to $40 \mathrm{Kms}$ from main university campus during 2009 to 2011. The observations were made on Mango (Mangifera indica L.) var. Amrapali in a randomized block design.

\section{Host range of different types of mealy bug on cultivated and wild crops}

Field observations were made on cultivated as well as wild host plant growing in the vicinity of the main mango orchards to determine the infestation of mango mealy bugs. Observations on infestation by the mealy bugs were recorded on twenty randomly selected infested plants.

The life cycle of mango mealy bug, Drosicha mangiferae

The studies on life cycle of mango mealy bug, Drosicha mangiferae were conducted under laboratory conditions. For this purpose plants were maintained in pots in the laboratory. The observations on the various developmental stages of mealy bug were recorded in the pots and number of days taken for each development stage was recorded separately.

\section{Mass culture of mango mealy bug}

The soil sample containing egg masses of mango mealy bug were dug out with the help of garden shovel and khurpa from the depth of $10-15 \mathrm{~cm}$ around a mango tree from Udheywalla orchard. Precautions were taken not to disturb the egg lying inside the soil samples. These samples were collected on first week of December during 2009. The collected egg masses were placed in the pots covered with muslin cloth with the help of rubber band. A small quantity of water was sprinkled as and when required over the soil samples, in each pot in order to ensure optimum moisture condition. The samples were kept under observation for determination of date of hatching of eggs emergence of nymphs. The emerging nymphs were transferred in the first week of January 2010 with the help of brush on other pots containing mango plants.

\section{Nymphal stage}

Freshly emerging nymphs were lifted in the first week of January 2010 on mango plants in pots. Ten such nymphs were individually placed in separate pots each representing a replicate. For proper sanitation and health of the nymphs was cleaned every day the nymphs were reared in the pots up to their first moulting where after they were transferred to another pot covered with net placed with rubber band. The nymphs from second instar onwards were continued to be reared in the pots till adult emergence. The maintenance of sanitation and provision fresh food to the development stages of individual replicate was ensured in the same manner $s$ in case of first instar nymphs. Right from the 
date of placement of newly hatched nymph to the date of emergence of adults each developing insect in each replicate was kept under constant observation. Every change observed during process of development of the nymph was recorded. The time taken from hatching to first moulting and subsequently to second and third moulting was recorded in each case. The period between hatching and moulting or between the two successive moults was considered as the developmental period of the particular instar. The time taken by the particular individual newly hatched nymph to reach or pupal stage, in case of female and male insect, respectively was considered as its nymphl period.

\section{Pre -pupal stage}

The developing male insects were found to remain somewhat sluggish and virtually stop feeding in the later part of their instar, the time taken from second moulting i.e., entering into thirds instar to the time of formation of pupa was considered as the pre- pupal period.

\section{Pupal stage}

In case of male insects the nymhs started formation of coccon in the later period of prepupal stage. The time taken from formation of pupa to the emergence of adult was considered as the period of pupal stage.

\section{Adult stage}

The period during which the adult male and female survive from the time of their emergence was recorded as their period of longevity.

\section{Sex ratio}

The sex ratio was determined on the basis of the number of insects entering the pupal stage and emerging directly adults after third moulting. The former group represented the males while latter one the females. The ratio between males and females was accordingly calculated from the data collected.

\section{Morpho measurements}

The length and breadth measurements of freshly emerging nymphs and eggs were computed with the help of Lieca microscope.

\section{Freshly emerging nymphs}

Ten freshly emerging nymphs were selected at random from mass culture, anaesthetized in 70 per cent alcohol and measured individually with help of Lieca microscope. Longitudinally from their body was measured from anterior to the posterior end while breadth measurements were recorded horizontally from end to end at middle of the body. The procedure described by Varshney (1985) was adopted for anaesthetizing the insect.

\section{Developing nymphs}

Ten nymphs from each developing instars were similarly selected at random, from mass culture, at the corresponding developmental stage. The measurements (length $\mathrm{x}$ breath) were recorded where utilised for computation and determination of the mean length and breadth of each instar.

\section{Eggs}

The randomly selected eggs were examined under a microscope and measured longitudinally with the help of Lieca microscope. These measurements were suggestive of the egg length and its breadth was determined by recording end to end measurements at the middle. These measurements were records were further used for computation and determination of the 
mean length and breadth of an egg. Ten specimens in each case (freshly emerging nymphs, developing nymphs and eggs) represented ten replicates.

\section{Statistical analysis}

The data have been subjected to analysis of variance as per the standard statistical techniques followed for randomized block design. Critical difference for treatments was computed at 5 per cent level of significance. Statistical analysis was done by using SPSS16 Software.

\section{Results and Discussion}

\section{Host ranges of mango mealy bugs}

Field survey and observations conducted during 2009 and 2011 showed that the insect pests in general and mango mealy bug in particular (Drosichia mangiferae) were invariably found on cultivated fruit and vegetable crops as well as on wild host crops growing in and around the fruit and vegetable crop ecosystem. Secondary sources or the wild host plants were also found serving as insect pest reservoir for the multiplication and dispersal of mealy bugs on main cultivated crops (Table 1). The pest was recorded on cultivated host plants such as Tomato (Lycopersicon esculentum); Lady finger (Abelmoschus esculentus); Bottle gourd (Lagenaria siceraria); Cucumber (Cucumis sativus); Brinjal (Solanum melongena); Chillies (Capsicum annum); Bitter gourd (Momordica charantia); Ridge gourd (Luffa cylindrica); Water melon (Cucumis melo); Ashwagandha (Rawllfia serpentia); Parthenium (Parthenium hysterophorus); China rose (Hibiscus rosa-sinensis); Nerium (Nerium indica); mulberry (Mours alba); Tur (Cajanus cajan L. Millsp); Black gram (Vigina mungo); Mango (Mangifera indica); Guava (Psidium guaja); Aonla (Emblica officinalis); Lemon (Citrus limon); Grape
(Vitis vinifera); Papaya (Carica papaya); Pomegranate (Punica granatum); Loquat (Eribotrya japonica); Custard Apple (Annona squamosa L.); Ber (Zizyphus mauritiana); Sweet orange (Citrus sinensis); Litchi (Litchi chinesis); Peach (Prunus persica); Banana (Musa paradisica); Imli (Tamarindus indica L.); Jack fruit (Artocarpus heterophyllus). Besides, the pest was found equally damaging in great extent to the wild plants viz., Datura (Datura stromonium); Husk tomato (Physalis maxima); Parthenium (Parthenium hysterophorus); China rose (Hibiscus rosasinensis); Bell flower (Tecoma grandiflora L.); Lantana (Lantana camera); Pipal (Ficus religiosa $\mathrm{L}$.

These wide ranges of host plants offer shelter to the different types of mealy bugs and maintain their population for some more time than the usual around the year. Four species of mealy bug species were identified in the region. These included Phenacoccus solenopsis (solanaceous mealy bug), Pseudococcus longispinus (Long-tailed mealy bug on mango), Drosicha mangiferae (Mango mealy bug) and Icerya sp. (Cottony cushion scale on aonla and mango). The studies revealed that more than 30 plants from 24 families were infested with mealy bugs. The highest number of plant species infested was from the family solanaceae (6). This was followed by cucurbitaceae (5), moraceae (3), rosaceae (2), malvaceae (2), and the 19 remaining families contributing few species each. Severe infestation of mango and ornamental plants were by $D$. mangiferae and $P$. solenopsis, respectively. Moreover, some crops were affected by several species of the suborder Homoptera other than mealy bugs; at times these other species were found coexisting on the same plant parts, forming complexes of different species of mealy bugs, Jassids, aphids, and white flies that made the level of infestation more and degree of damage enhanced. 
Biology of mango mealy bug, $D$. mangiferae

Biology and duration of various life/developmental stages are presented in table 2 (Plate 1) which revealed that the first instar nymph took mean time of $51.1 \pm 2.64$ (range 39 to 60) days for its development. This period differed significantly from the developmental period of rest of the instars including adults.

The second and third instars completed their development in relatively lesser period of $22.7 \pm 2.08$ (range 13 to 32 ) days and $32.9 \pm$ 1.15 (range 16 to 45) days, respectively. These two instars did not exhibit any significant difference in terms of their period of development is concerned. The third instar nymph of male represent its pre-pupal stage which completed its development within a mean period $6.8 \pm 0.58$ (range 4 to 9 ) days. The pupal period of male lasted for $6.1 \pm 1.00$ (range 5 to 9) days.

The male insects at their pre-pupal, pupal and adult stage did not show any significant difference in between the periods of their development. The female nymphal development completed within a period of $125.5 \pm 10.17$ (range 103 to 190) days, whereas male took less period of $110.5 \pm$ 10.01 (range 75 to 130) days only. Adult longevity in case of female was recorded as $49.8 \pm 1.13$ (range 39 to 69 ) days which was significantly different from that of male in which case it was noted as $6.8 \pm 0.58$ (range 6 to 8) days.

The seasonal activity of mango mealy bugs were recorded from $1^{\text {st }}$ standard week up to $20^{\text {th }}$ standard week thereafter the gravid female come/strolled down and entered inside the cracks and cravices for laying the eggs. The eggs laid in the soil cracks and cravices remain in diapause from June to the next season in January. With the increase in temperature the eggs were hatched and newly emerged nymphs/crawlers started climbing on trees and crops and settled on tender twigs.

The total period of activity (pooled data of two generation) from hatching of eggs to adult mortality was computed as $125.5 \pm$ 10.17 (range 103 to 190 ) days and $110.5 \pm$ 10.01 (range 75 to 130) days in case of females and males, respectively.

The nymphs passed through three instars during the course of development while having only one generation in a year. Similar observations were also recorded in generation 2 (Table 2).

Mean morphometric measurements of various developmental stages of $D$. mangiferae

The data on measurements of length and breadth of eggs, developing nymphs and adults (male and female) of mango mealy bug are presented in table 3 .

Eggs

The mean length $\times$ breadth of an egg recorded and computed as $1.9 \pm 0.31 \times 0.8 \pm 0.4$ (range $1-3 \times 0-1) \mathrm{mm}$.

\section{Nymphs}

The mean body length $\times$ breadth of first instar nymph was $1.3 \pm 0.4 \times 0.7 \pm 0.4$ (range $1.2 \times 0$ 2) $\mathrm{mm}$. The second instar female and male nymph measured $2.7 \pm 1.6 \times 2.1 \pm 0.4$ (range 1 $3 \times 1-3) \mathrm{mm}$, respectively. The third instar female and male nymph measured $4.1 \pm 1.6 \times$ $2.0 \pm 0.7$ (range $2-4 \times 2-4$ ) $\mathrm{mm}$, respectively. The male pupa measured $4.6 \pm 1.7 \times 3.0 \pm 0.9$ (range 3-5 × 3-6) (Table 3). 
Plate.1 Life cycle (Biology) of mango mealy bug on Mango
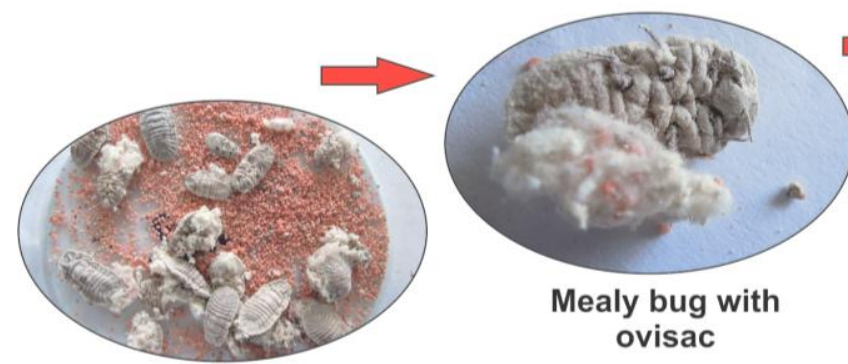

Female mealy bug with ovisac and eggs

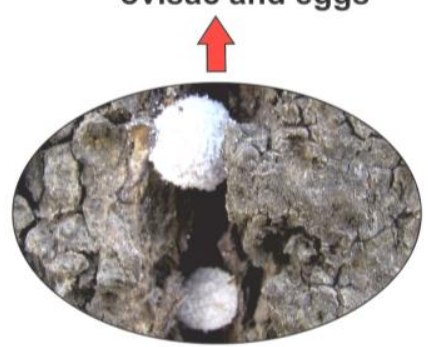

\section{Life cycle (biology)} of mango mealy bug on mango

Gravid female hiding in cracks

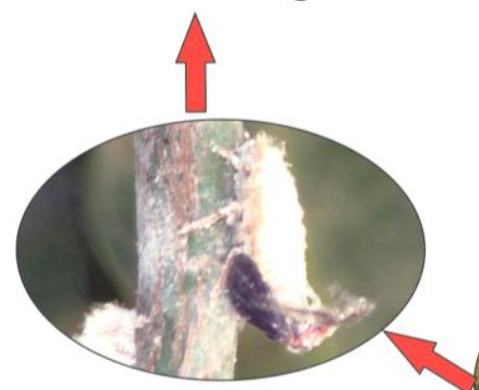

Copulation of mealy bug

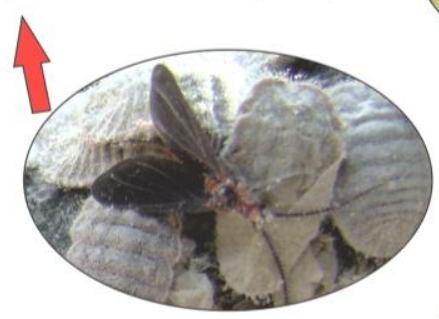

Male of mealy bug
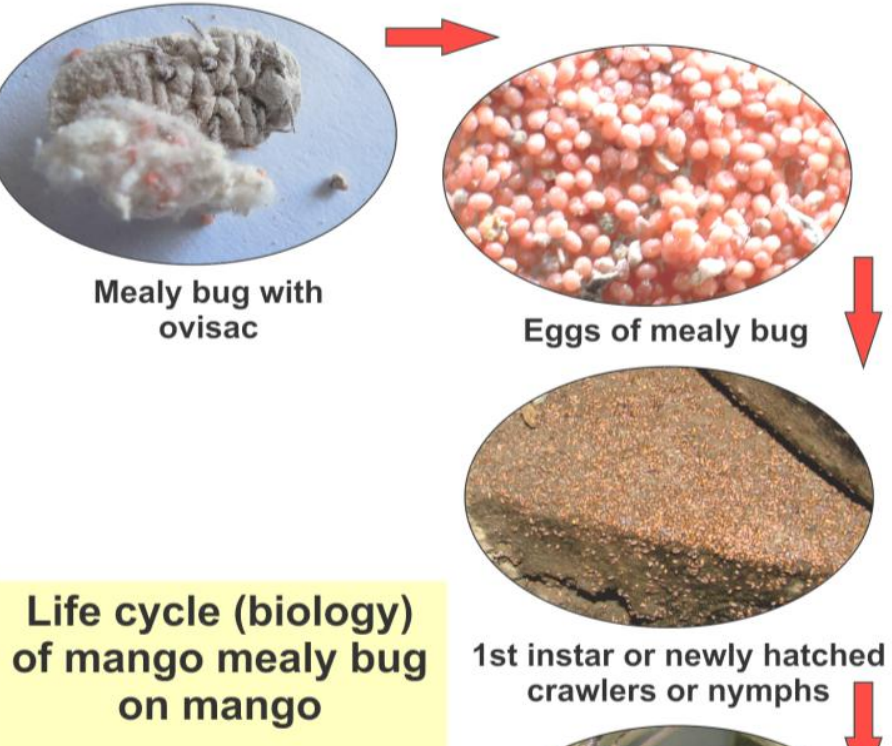

1st instar or newly hatched crawlers or nymphs

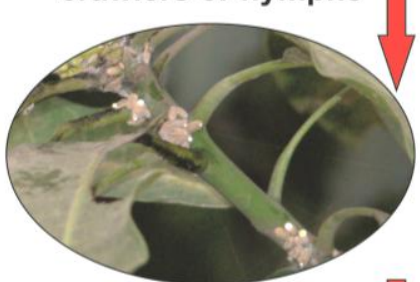

2nd instar nymphs

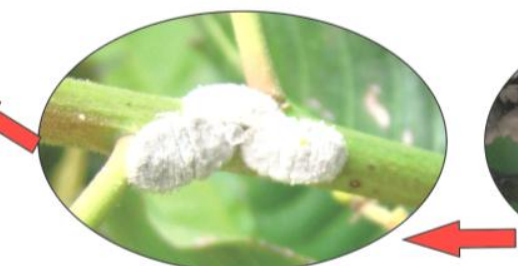

Female mealy bug
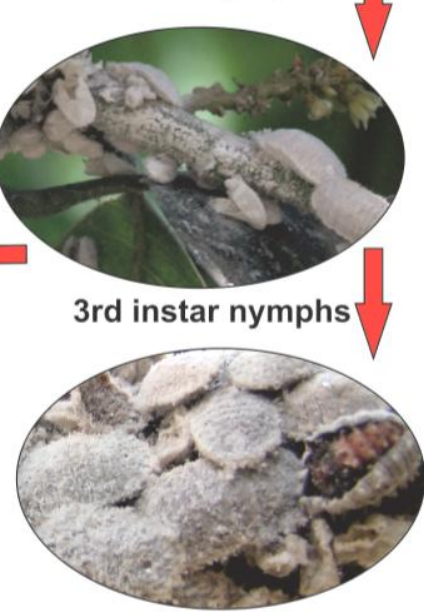

4th instar nymphs

Pupation before male emergence

(Photographs courtesy: Dr. Uma Shankar) 
Table.1 Different species of mealy bugs recorded on various host crops during 2010 and 2011

\begin{tabular}{|c|c|c|c|}
\hline S. No. & Host plants & Botanical Name & Family \\
\hline 1. & Tomato & Lycopersicon esculentum & Solanaceae \\
\hline 2. & Okra & Abelmoschus esculentus & Malvaceae \\
\hline 3. & Bottle gourd & Lagenaria siceraria & Cucurbitaceae \\
\hline 4. & Cucumber & Cucumis sativus & Cucurbitaceae \\
\hline 5. & Brinjal & Solanum melongena & Solanaceae \\
\hline 6. & Chillies & Capsicum annum & Solanaceae \\
\hline 7. & Bitter gourd & Momordica charantia & Cucurbitaceae \\
\hline 8. & Ridge gourd & Luffa cylindrica & Cucurbitaceae \\
\hline 9. & Water melon & Cucumis melo & Cucurbitaceae \\
\hline 10. & Ashwagandha & Rawllfia serpentia & Solanaceae \\
\hline 11. & Dhatura & Datura stromonium & Solanaceae \\
\hline 12. & Husk tomato & Physalis maxima & Solanaceae \\
\hline 13. & Parthenium & Parthenium hysterophorus & Asteraceae \\
\hline 14. & China rose & Hibiscus rosa-sinensis & Malvaceae \\
\hline 15. & Bell flower & Tecoma grandiflora $\mathrm{L}$. & Bignoniaceae \\
\hline 16. & Nerium & Nerium indica & Apocynaceae \\
\hline 17. & mulberry & Morus alba & Moraceae \\
\hline 18. & Lantana & Lantana camera & Verbenaceae \\
\hline 19. & Pipal & Ficus religiosa L. & Moraceae \\
\hline 20. & Tur & Cajanus cajan (L.) Millsp. & Fabaceae \\
\hline 21. & Black gram & Vigina mungo & Legumeaeouceae \\
\hline 22. & Mango & Mangifera indica & Anacardiaceae \\
\hline 23. & Guava & Psidium guajava & Myrtaceae \\
\hline 24. & Aonla & Emblica officinalis & Euphorbiaceae \\
\hline 25. & Lemon & Citrus limon & Rutaceae \\
\hline 26. & Grape & Vitis vinifera & Vitaceae \\
\hline 27. & Papaya & Carica papaya & Caricaceae \\
\hline 28. & Pomegranate & Punica granatum & Punicaceae \\
\hline 29. & Loquat & Eribotrya japonica & Rosaceae \\
\hline 30. & Custard Apple & Annona squamosa L. & Annonaceae \\
\hline 31. & Imli & Tamarindus indica L. & Caesalpinaceae \\
\hline 32. & Ber & Zizyphus mauritiana & Rhamnaceae \\
\hline 33. & Sweet orange & Citrus sinensis & Rutaceae \\
\hline 34. & Litchi & Litchi chinesis & Sapindaceae \\
\hline 35. & Peach & Prunus persica & Rosaceae \\
\hline 36. & Banana & Musa paradisica & Musaceae \\
\hline 37. & Jack fruit & Artocarpus heterophyllus & Moraceae \\
\hline
\end{tabular}


Table.2 Biology and duration of various life/ developmental stages of mealy bug, D. mangiferae

\begin{tabular}{|c|c|c|c|c|c|c|c|c|c|c|}
\hline \multirow[t]{3}{*}{ Life Stage } & \multicolumn{2}{|l|}{ Duration days } & \multicolumn{4}{|c|}{ Temperature } & \multicolumn{4}{|c|}{ Relative humidity } \\
\hline & \multirow[t]{2}{*}{ Generation 1} & \multirow[t]{2}{*}{ Generation 2} & \multicolumn{2}{|c|}{ Generation 1} & \multicolumn{2}{|c|}{ Generation 2} & \multicolumn{2}{|c|}{ Generation 1} & \multicolumn{2}{|c|}{ Generation 2} \\
\hline & & & Max. & Min. & Max. & Min. & Morng. & Even. & Morng. & Even. \\
\hline Eggs & $\begin{array}{l}\text { Diapause from } 1^{\text {st }} \\
\text { June to } 3^{\text {rd }} \text { Jan. }\end{array}$ & $\begin{array}{l}\text { Diapuse from } 1^{\text {st }} \\
\text { June to } 1^{\text {st }} \text { Jan }\end{array}$ & & & & & & & & \\
\hline $1^{\text {st }}$ instar & $51.1 \pm 2.64(39-60)$ & $\begin{array}{l}52.2 \pm 1.00 \\
(41-61) \\
\end{array}$ & $17.2 \pm 1.5$ & $4.25 \pm 1.3$ & $17 \pm 1.2$ & $4.1 \pm 1.2$ & $90 \pm 3.1$ & $58 \pm 3$ & $91 \pm 2.1$ & $57 \pm 1.2$ \\
\hline $2^{\text {nd }}$ instar & $\begin{array}{l}22.7 \pm 2.08 \\
(13-32) \\
\end{array}$ & $\begin{array}{l}22.6 \pm 2.52 \\
(13-31) \\
\end{array}$ & $22.3 \pm 1.4$ & $9.95 \pm 1.8$ & $21.1 \pm 1.2$ & $8.85 \pm 1.8$ & $83.5 \pm 4.5$ & $48.5 \pm 3.5$ & $82.4 \pm 1.2$ & $47.5 \pm 2$ \\
\hline $3^{\text {rd }}$ instar & $\begin{array}{l}32.9 \pm 1.15 \\
(16-45) \\
\end{array}$ & $\begin{array}{l}32.4 \pm 1.16 \\
(16-44) \\
\end{array}$ & $34.4 \pm 2.1$ & $15.2 \pm 1.5$ & $34 \pm 1.2$ & $14.5 \pm 1.5$ & $77 \pm 3.1$ & $38.0 \pm 2.0$ & $76 \pm 1.5$ & $38.5 \pm 1.5$ \\
\hline Adult female & $\begin{array}{l}49.8 \pm 1.13 \\
(39-69)\end{array}$ & $\begin{array}{l}44.7 \pm 4.04 \\
(25-53)\end{array}$ & $38.0 \pm 2.0$ & $21 \pm 1.5$ & $39 \pm 1.5$ & $21.5 \pm 1.5$ & $55 \pm 2$ & $20.5 \pm 2$ & $56 \pm 2.5$ & $38.0 \pm 2$ \\
\hline $1^{\text {st }}$ instar & $\begin{array}{l}51.1 \pm 2.64 \\
(39-60) \\
\end{array}$ & $\begin{array}{l}52.2 \pm 1.00 \\
(41-61) \\
\end{array}$ & $17.2 \pm 1.5$ & $4.25 \pm 1.3$ & $17 \pm 1.2$ & $4.1 \pm 1.2$ & $90 \pm 3.1$ & $58 \pm 3$ & $91 \pm 2.1$ & $57 \pm 1.2$ \\
\hline $2^{\text {nd }}$ instar & $\begin{array}{l}22.7 \pm 2.08 \\
(13-32) \\
\end{array}$ & $\begin{array}{l}22.6 \pm 2.52 \\
(13-31)\end{array}$ & $22.3 \pm 1.4$ & $9.95 \pm 1.8$ & $21.1 \pm 1.2$ & $8.85 \pm 1.8$ & $83.5 \pm 4.5$ & $48.5 \pm 3.5$ & $82.4 \pm 1.2$ & $47.5 \pm 2$ \\
\hline $\begin{array}{l}\text { 3rd instar } \\
\text { Pre pupa }\end{array}$ & $\begin{array}{l}6.8 \pm 0.58 \\
(4-9)\end{array}$ & $\begin{array}{l}6-7 \pm 0.88 \\
(5-9)\end{array}$ & $22 \pm 2.1$ & $9.5 \pm 1.5$ & $21 \pm 2.1$ & $8 \pm 1.5$ & $82 \pm 2.1$ & $48.5 \pm 3.5$ & $82.4 \pm 1.2$ & $47.5 \pm 2$ \\
\hline Pupa & $\begin{array}{l}6.1 \pm 1.00 \\
5-9\end{array}$ & $\begin{array}{l}6.2 \pm 0.58 \\
6-8\end{array}$ & $22.1 \pm 2.1$ & $9.5 \pm 1.5$ & $21 \pm 2.1$ & $8 \pm 1.5$ & $82 \pm 2.1$ & $48.5 \pm 3.5$ & $82.4 \pm 1.2$ & $47.5 \pm 2$ \\
\hline Adult male & $\begin{array}{l}6.8 \pm 0.58 \\
(6-8)\end{array}$ & $\begin{array}{l}6.2 \pm 0.58 \\
(6-9)\end{array}$ & $38.0 \pm 2.0$ & $21 \pm 1.5$ & $39 \pm 1.5$ & $21.5 \pm 1.5$ & $55 \pm 3.1$ & $20.5 \pm 2$ & $56 \pm 2.5$ & $38.0 \pm 2$ \\
\hline C.D( $\leq \mathbf{0 . 0 5})$ & 5.20 & 4.31 & & & & & & & & \\
\hline S.E(m) & 1.72 & 1.43 & & & & & & & & \\
\hline
\end{tabular}

Total period of activity of female $=125.5 \pm 10.17$, Range $=103-190$ days; Total period of activity Male=110.5 \pm 10.01 , Range= $=75-130$ day

Table.3 Mean morphometric measurements of various life/ developmental stages of D. mangiferae

\begin{tabular}{|l|l|l|l|}
\hline Sex & Developmental Stage & \multicolumn{1}{|c|}{ Length $\times$ Breadth } & Range \\
\hline & Egg & $1.9 \pm 0.31 \times 0.8 \pm 0.4$ & $(1-3) \times(0-1)$ \\
\hline \multirow{5}{*}{ Female } & First instar nymph & $1.3 \pm 0.4 \times 0.7 \pm 0.4$ & $(1.2) \times(0-2)$ \\
\cline { 2 - 4 } & Second instar nymph & $2.7 \pm 1.6 \times 2.1 \pm 0.4$ & $(1-3) \times(1-3)$ \\
\cline { 2 - 4 } & Third instar nymph & $4.1 \pm 1.6 \times 2.0 \pm 0.7$ & $(2-4) \times(2-4)$ \\
\cline { 2 - 4 } & Adult & $4.7 \pm 1.8 \times 1.5 \pm 0.5$ & $(6-10) \times(2-5)$ \\
\hline Male & First instar nymph & $1.3 \pm 0.4 \times 0.7 \pm 0.4$ & $(1.2) \times(0-2)$ \\
\hline & Second instar nymph & $2.7 \pm 1.6 \times 2.1 \pm 0.4$ & $(2-4) \times(1-3)$ \\
\hline & Third instar nymph & $4.1 \pm 1.6 \times 2.0 \pm 0.7$ & $(3-5) \times(3-6)$ \\
\hline & Pupa & $4.6 \pm 1.7 \times 3.0 \pm 0.9$ & $(4-8) \times(2-5)$ \\
\hline
\end{tabular}




\section{Adults}

The adult female and male measured $4.7 \pm 1.8$ $\times 1.5 \pm 0.5$ (range $6-10 \times 2-5) \mathrm{mm}$ and $4.5 \pm 1.7$ $\times 1.5 \pm 0.5$ (range $4-8 \times 2-5) \mathrm{mm}$, respectively.

\section{Fecundity}

The data on fecundity collected on showed that the eggs were laid in a mass in a silken pouch. In some cases, the egg pouches were observed to be attached to the posterior side of the dead females below the surface of the soil. The mean number of eggs laid per female was recorded as $122.2 \pm 22.70$ (range 85-133). The laying period continued for about 20-25 days. The eggs were initially light pink and later turned to reddish brown in colour.

\section{Diapause}

The eggs laid earlier in the previous season were noted to be available up to a depth of 20 $\mathrm{cm}$ in the soil around the mango trees in the experimental orchard. This behaviour coupled with observations recording hatching of eggs and time of laying from end of May to June suggests that the insect remains in diapause, in egg stage, from June to early late December under Jammu conditions.

\section{Period of activity and generations}

First appearance of nymphs in generation 1 was observed on $1^{\text {st }}$ week of new year in the fields which was synchronized with the minimum and maximum temperature of $4.25^{\circ} \mathrm{C}$ and $17.2^{\circ} \mathrm{C}$ respectively and the relative humidity of 90 per cent $(08: 30 \mathrm{~h})$ and 58 per cent $(17: 30 \mathrm{~h})$. The insect was recorded to have only one generation during the entire year as evinced by the mortality of adult male and female in the ending May, respectively. In generation 2, similar observations were also recorded. After third instar, the numphs of mealy bug could not moult in the laboratory.

The present findings are in conformity with the results obtained by Suresh and Kavitha (2008) found that five scale insect pest species such as Phenacoccus solenopsis Tinsley, Coccidohystrix insolita Green, Rastrococcus iceryoides Green, Cerococcus indicus Maskell and Saissetia coffeae Walker on parthenium, cotton, hibiscus and crotons in Coimbtore, Tamil Nadu. Similarly, Godse et al., (2003) found seven species of mealy bugs on mango (Perissopneumon sp. Ferrisia virgata, Planococcoides robustus, Rastrococcus invadens, Planococcus sp., Cataenococcus sp. and Icerya aegyptiaca) in Maharashtra, India. Furthermore, Haq and Akmal (1960), Prasad and Singh (1976), Tandon and Lal (1978), Tandon and Verghese (1985), Khan (2001), Narula (2003), Culik et al., (2003), Tanwar et al., (2007), Rajendran (2009), Dhawan et al., (2009), Atwal and Dhaliwal (2009), Nagrare et al., (2009) and Wih and Billah (2012) were established the similar records and stated that mango mealy bug ( $D$. mangiferae) attack on a variety of other fruit trees and dangerous for mango crop.

The observed longevity of adult females for a period of $46.3+3.4$ and that of males for $6.7+1.41$ days is similar to the findings of Chandra et al., (1987) who have recorded the life of males and females as 4-6 and 18-51 days respectively. The females lived much longer life which was six times the longevity period of males. The nymphs of both male and female bugs were seen to become most active in their looks and behaviour after entering the second stage of their development following their first moulting. The current results are in conformity with the Rehman and Latif (1944), Atwal et al., (1969), Srivastava et al., (1973), Bindra and Sohi (1974), Atwal (1976), Tandon and Lal 
(1979), Sandhu et al., (1979) and Ashfaq et al., (2005). The observation on the studies related to the number of generations revealed that the insect is univoltine which retified the reports of Chandra et al., (1987), Atwal (1969), Srivastava et al., (1973), Ashfaq et al., (2005) who have also documented one generation in case of mango mealy bug in Punjab, Bihar and Uttar Pradesh.

Mango is an important fruit crops grown in Jammu region which harbours a large magnitude of insect pests. Among them, mango mealy bug is one such problematic pest causing huge damage to several fruit, vegetable and other crops including mango. The host range studies revealed that more than 30 species were severely infested with mealy bugs in the Jammu region. Life cycle studies will be helpful in formulation of the optimum time to initiate the control measures to combat this dreaded pests.

\section{References}

Ashfaq, M., Khan, R. A., Khan, M. A., Rasheed, F., and Hafeez, S. 2005. Complete control of mango mealy bug using funnel type slippery trap. Pakistan Entomology, 27(1): 45-48.

Atwal, A. S., 1976. Agriculture Pests of India and South East Asia. Kalyani Publishers, Ludhiana, India, pp. 224227.

Atwal, A. S., and Dhaliwal, G. S. 2009. Agricultural Pests of South Asia and their Mangement. Kalyani Publishers, New Delhi.

Atwal, A.S., 1969. Insect pests of mango and their control. Punjab Horticulture Journal, 3(2-1): 235-58.

Bindra, O. S., and Sohi, B. S. 1974. A note on control of mango mealy bug in Punjab. Indian Journal of Horticulture, 31(1): 102-103.

Chandra, A., Bhati, D. P. S. and Singh, K. M. 1987. Bionomics of mango mealy bug,
Drosicha mangiferae Green. Bulletin of Entomology, 28 (2): 145-52.

Culik, M. P., Martinsm, D. dos S. and Entura, J. A. 2003. Indice de Artropodes Pragas do Mamoeiro (Carica papaya L.). Vitoria, Espirito Santo, Brazil: INCAPER, pp. 48

Dhawan, A. K., and Aneja, A. And Saini, S. 2009. First record of Phenococcus solenopsis Tinsely (Homoptera: Pseudococcidae) on cotton in Punjab. Journal of Insect Science, 22(3): 309310.

Godse, S. K., and Bhole, S. R. 2003. Mango mealy bug fauna of Konkan region of Maharashtra. Insect Environment, 9: 4, 157.

Haq, K. A., and Akmal, M. 1960. Mango mealy bug and its control. Fruit J., 23(82-83): 199-202.

Khan, M. A., 2001. Control of insect pests of mango. Proceedinds of International Mango workshop, 27 Feb-1Mar. Direct. Agric-Multan Region, Punjab, pp. 224.

Nagrare, V. S., Kranthi, S., Biradar, V. K. Zadi, N. N., Sangode, V., Kakde, G., Shukla, R. M., Shivare, D., Khadi, B. M. and Kranthi, K. R. 2009. Widespread infestation of the exotic Mealybug species, Phenacoccus solenopsis (Tinsely), (Hemiptera; Pseudococcidae) on cotton in India. Bulletin of Entomological Research, 99: 537-541.

Narula, S., 2003. Nip mango mealy bug in the bud now Spectrum, Sunday14, 2003. Tribune (Garden Life) India.

Prasad, V. G., and Singh, R. K. 1976. Prevalence and control of Mango mealy bug Drosicha mangiferae (Green) in Bihar. Indian Journal of Entomology, 38 (3): 214-24.

Rajendran, T. P., 2009. Integrated Pest Management-policy directions in the context of climate change. In: Ramamurthy, V. V. Gupta, G. P. and 
Puri, S. N. (eds.) Proceedings of National Symposium, IPM Strategies to combat Emerging Pests in the Current Scenario of Climate Change. January 28-30, 2009, Pasighat, Arunachal Pradesh, pp. 8-13.

Rehman, K. A., and Latif, M. A. 1944. Description, bionomics and control of gaint mealy bug, Drosicha stebbingi, Green (Homoptera: Coccidae) Bulletin of Entomological Research, 35: 197209.

Sandhu, G. S., Sohi, A. S., Batra, R. C. and Bhalla, J. S. 1979. Stem infection for the control of mango pests with particular reference to mango mealy bug, D. mangiferae Green (Hemiptera: Margarodidae). Proceedings of Mango Worker Meeting Held at Goa. pp. 248249.

Sauco, V., 1997. Mango World Production (Outside Israel, Egypt and India). Acta Hort., 455:15-22.

Srivastava, A. S., Singh, Y. P., Pandey, R. C. and Awasthi, B. K. 1973. Bionomics and Control of mango mealy bug. World Crops, 25(2): 87-88.

Suresh, S., and Kavita. 2008.Seasonal incidence of economically important coccidae pest in Tamil Nadu. In: Proceedings of the $x i$ International symposim on scale insect studies
(Branco, M. Franco Jc Hodgson C. J, eds.) held on 24-27 September 2007 at Oeiras. Portugal USA press, 2008.pp. 285-291.

Tandon, P. L., and Lal, B. 1981. Effectiveness of different banding materials for preventing migration of $D$. mangiferae Green. Indian Journal of Entomology, 43(2): 189-191.

Tandon, P. L., and Lal, B. 1978. The mango coccid, Rastrococcus iceryoides Green (Homoptera: Coccidae) and its natural enemies. Current Science, (13): 46-48.

Tandon, P. L., and Lal, B. 1979. Comparative efficacy of Synthetic Garlic oil with some modern insecticides against Drosicha mangiferae Green. Progressive Horticulture, 12(3): 62-65.

Tandon, P. L., and Verghese, A. 1985. World List of Insect, Mite and other pests of Mango, pp. 22. Technical Document No. 5, IIHR, Banglore.

Tanwar, R. K., Jeyakumar, Pand Monga, D. 2007. Mealy bug and their management. National Center for Intergated Pest Mangement, New Delhi.

Varshney, 1985.

Wih, K., and Billah, M. K. 2012. Diversity of Fruit Flies and Mango mealy bug in the upper west Region of Ghana. Journal of Development in Sustainable Agriculture, 7:39-45.

\section{How to cite this article:}

Bandana Bhau, Uma Shankar and Abrol, D.P. 2017. Studies on Host Range and Biology of Mango Mealy Bug (Drosicha mangiferae) in Jammu Region. Int.J.Curr.Microbiol.App.Sci. 6(9): 230-240. doi: https://doi.org/10.20546/ijcmas.2017.609.031 